\title{
Stimulasi Pertumbuhan Stek Pucuk Torbangun (Plectranthus amboinicus Spreng.)
}

\section{Growth Stimulation on Shoot Cutting of Torbangun (Plectranthus amboinicus Spreng.)}

\author{
Karmila, Tatiek Kartika Suharsi* \\ Departemen Agronomi dan Hortikultura, Fakultas Pertanian, Institut Pertanian Bogor \\ Jalan Meranti, Kampus IPB Darmaga, Bogor 16680, Indonesia \\ Telp.\&Faks.62-251-8629353, e-mail: agronipb@indo.net.id \\ *Penulis untuk korespondensi: tsuharsi@yahoo.co.id
}

Disetujui 17 Mei 2017/Published online 22 Mei 2017

\begin{abstract}
Torbangun is an indigenous plant that its leaves used as vegetable, herbal plant, and source of micro nutrient. Torbangun propagation still done vegetatively by stem cutting, but it has not been developed. The aims of this research was to study the effective stimulant for the best growth of torbangun shoot cutting. This research was conducted at Dramaga experimental station and Seed Storage and Seed Quality Testing Laboratory of Institut Pertanian Bogor from April until July 2015. The experiment was laid out in randomized completely block design one factor that consist of without stimulant application, cutting + synthetic stimulant $100 \mathrm{ppm}$, cutting + synthetic stimulant $150 \mathrm{ppm}$, cutting + natural stimulant of ruminants's urine (cow's urine) $15 \%$, cutting + natural stimulant of ruminants's urine $25 \%$, cutting + natural stimulant of shallot extract $40 \%$, and cutting + natural stimulant of shallot extract $60 \%$ as treatment. There were three replications and each treatment consisted of eight cuttings, in this way a total was 168 cuttings. All concentrated neither natural stimulant nor synthetic stimulant did not stimulate growth of torbangun shoot cutting effectively.
\end{abstract}

Keywords: cow's urine, indigenous, shallot extract, stimulant, vegetative propagation

\begin{abstract}
ABSTRAK
Torbangun (Plectranthus amboinicus Spreng.) merupakan tanaman indigenous yang dimanfaatkan daunnya sebagai sayuran, obat, dan sumber zat gizi mikro. Sistem perbanyakan torbangun saat ini hanya dilakukan secara vegetatif yaitu dengan setek batang, namun metode perbanyakan dengan setek belum banyak dikembangkan. Tujuan penelitian ini yaitu untuk mempelajari peran stimulan yang efektif untuk pertumbuhan setek pucuk torbangun. Penelitian dilaksanakan di Kebun Percobaan Babakan Dramaga dan Laboratorium Pengujian Mutu dan Penyimpanan Benih Institut Pertanian Bogor pada bulan April 2015 sampai Juli 2015. Rancangan yang digunakan adalah rancangan acak kelompok satu faktor yang terdiri dari tujuh taraf perlakuan yaitu setek tanpa perlakuan stimulan, setek + stimulan sintetik 100 ppm, setek + stimulan sintetik 150 ppm, setek + stimulan alami urin sapi $15 \%$, setek + stimulan alami urin sapi $25 \%$, setek + stimulan alami ekstrak bawang merah 40\%, dan setek + stimulan alami ekstrak bawang merah 60\%. Setiap perlakuan terdiri dari tiga ulangan. Setiap satuan percobaan terdiri dari delapan setek sehingga didapatkan 168 setek. Stimulan alami dan sintetik tidak efektif terhadap pertumbuhan setek pucuk torbangun.
\end{abstract}

Kata kunci: ekstrak bawang merah, indigenous, perbanyakan vegetatif, stimulan, urin sapi 


\section{PENDAHULUAN}

Tanaman indigenous adalah tanaman lokal atau introduksi yang dikenal dan diusahakan oleh masyarakat (Diperta Jabar 2012). Namun sekarang tidak banyak masyarakat yang mengetahui, mengkonsumsi, atau bahkan memanfaatkan khasiat-khasiat yang terkandung didalam tanaman indigenous. Keberadaan tanaman indigenous yang mulai terancam punah perlu kita lestarikan dan manfaatkan sebagai sumber plasma nutfah yang memiliki nilai ekonomi yang tinggi.

Tanaman torbangun merupakan salah satu jenis tanaman indigenous yang berpotensi besar untuk dikembangkan, karena terdapat tiga senyawa yang terkandung dalam daun torbangun, yaitu senyawa lactagogum, senyawa farmaseutika, dan komponen gizi. Senyawa lactagogum bermanfaat meningkatkan produksi ASI, sedangkan senyawa farmaseutika yaitu senyawa yang bersifat buffer, antibakterial, dan antioksidan. Komponen-komponen gizi yang terkandung dalam daun torbangun terdiri dari vitamin $\mathrm{C}$, vitamin $\mathrm{B} 1$, vitamin $\mathrm{B} 12, \beta$ karoten, niasin, karvakrol, kalsium, asam-asam lemak, oksalat, dan serat (Rumetor 2008).

Kaliappan dan Viswanathan (2008) menyatakan daun torbangun dapat dimanfaatkan untuk obat malaria, batu ginjal, asma, anti kanker, dan tumor. Beberapa pengembangan produk tanaman torbangun diantaranya minuman suplemen berbahan dasar daun torbangun untuk wanita penderita PMS (Pramenstruasi Syndrome) (Alfitra 2010) dan kue kering yang dibuat dengan penambahan tepung torbangun sebagai sumber zat gizi mikro (Dewi 2011).

Tanaman torbangun umumnya jarang berbunga. Hal ini dapat menjadi kendala perbanyakan tanaman torbangun secara generatif. Sistem perbanyakan tanaman torbangun saat ini banyak dilakukan secara vegetatif, salah satunya menggunakan setek. Perbanyakan vegetatif dengan setek membutuhkan waktu yang relatif lebih cepat dan menghasilkan keturunan yang memiliki sifat yang sama dengan induknya.

Kebutuhan bahan setek torbangun semakin banyak, sementara ketersediaan tanaman torbangun masih terbatas. Pengembangan sistem perbanyakan tanaman torbangun penting dilakukan untuk menghasilkan tanaman torbangun yang bermutu, seragam, dalam jumlah banyak, efisien, dan murah. Oleh karena itu diperlukan stimulasi pertumbuhan setek torbangun menggunakan stimulan sintetik maupun alami. Stimulan sintetik yang dapat digunakan salah satunya yaitu Zat Pengatur Tumbuh (ZPT) berupa auksin sintetik dalam bentuk formulasi senyawasenyawa kimia tertentu. Stimulan alami berasal dari jaringan tanaman contohnya pada umbi bawang merah dan juga limbah hewan ternak seperti urin sapi.

Penelitian mengenai tanaman torbangun selama ini hanya sebatas farmakologi saja, tidak diimbangi oleh teknik perbanyakannya. Oleh karena itu diperlukan penelitian mengenai teknologi produksi setek torbangun yaitu stimulasi pertumbuhan setek menggunakan stimulan sintetik dan alami. Penelitian ini bertujuan untuk mendapatkan stimulan sintetik dan alami yang efektif untuk pertumbuhan setek pucuk torbangun.

\section{BAHAN DAN METODE}

Percobaan dilaksanakan di Kebun Percobaan Babakan Dramaga, Institut Pertanian Bogor, pada bulan April 2015 sampai dengan Juli 2015. Kebun percobaan terletak pada ketinggian $500 \mathrm{~m}$ dpl. Pengamatan pascapanen dilaksanakan di Laboratorium Pengujian Mutu dan Penyimpanan Benih, Departemen Agronomi dan Hortikultura, Institut Pertanian Bogor.

Bahan yang digunakan yaitu tanaman torbangun berumur dua bulan dari Unit Konservasi dan Budi Daya Biofarmaka Institut Pertanian Bogor, polybag, media tanam campuran tanah topsoil dan pupuk kandang 1:1, aquades, furadan $3 \mathrm{G}$, label, benang, paranet dengan intensitas naungan $60 \%$, stimulan alami umbi bawang merah varietas Bima, stimulan alami urin sapi (sapi betina jenis pedaging, tidak sedang hamil, berumur satu tahun, makanan sehariharinya hijauan rumputan dan konsentrat), serta stimulan sintetik (kandungan bahan aktif: naftalenasetamida $0.067 \%, 2$ metil 1 naftalenasetamida $0.013 \%, 2$ metil 1 naftalen asetat $0.03 \%$, indole 3 butirat $0.057 \%$, dan tiram $4 \%$ ). Peralatan yang digunakan selama penelitian antara lain timbangan analitik, gunting setek, gembor, wadah plastik, mortar, oven, alat ukur, alat-alat pertanian, alat tulis, dan alat dokumentasi.

Rancangan percobaan yang digunakan dalam penelitian ini yaitu Rancangan Acak Kelompok (RAK) satu faktor yang terdiri dari tujuh taraf perlakuan yaitu setek tanpa perlakuan stimulan (A0), setek + stimulan sintetik 100 ppm (A1), setek + stimulan sintetik $150 \mathrm{ppm}$ (A2), setek + stimulan alami urin sapi $15 \%$ (A3), setek + stimulan alami urin sapi $25 \%$ (A4), setek + stimulan alami ekstrak bawang merah 40\% (A5), dan setek + stimulan alami ekstrak bawang merah $60 \%$ (A6). Setiap perlakuan terdiri dari tiga ulangan. Setiap satuan percobaan terdiri dari delapan setek 
sehingga digunakan 168 setek. Analisis data menggunakan uji $\mathrm{F}$, jika terdapat pengaruh nyata maka dilakukan uji lanjut DMRT (Duncan Multiple Range Test) pada taraf 5\%. Perangkat lunak yang digunakan adalah Statistical Tool for Agricultural Research (STAR) versi 2.0.1.

Percobaan pendahuluan dilakukan pada minggu ke-1 dan ke-2 bulan Maret 2015 yaitu dua minggu sebelum penelitian dilaksanakan. Percobaan pendahuluan dilakukan untuk mengamati jumlah akar yang muncul pada setek pucuk torbangun dengan perlakuan yang sama sesuai perlakuan dalam penelitian yang akan dilaksanakan. Pengamatan dilakukan pada minggu ke-2 setelah tanam.

Pelaksanaan penelitian dimulai dengan membersihkan lahan dari kotoran dan gulma yang tumbuh, kemudian dipasang paranet dengan intensitas naungan $60 \%$. Media tanam berupa tanah topsoil dan pupuk kandang dengan perbandingan volume (1:1) dimasukkan ke dalam polybag. Pemotongan setek dilakukan pada pucuk yang bercabang atau sedikit dibawah pucuk yang bercabang dengan kemiringan 45 derajat. Panjang setek pucuk yang digunakan sebesar $10.5 \mathrm{~cm}$, masing-masing disisakan empat helai daun dan dipotong $2 / 3$ bagiannya untuk mengurangi transpirasi pada daun.

Setek yang tidak diberi perlakuan stimulan (kontrol) segera ditanam. Larutan stimulan sintetik dibuat dengan konsentrasi 100 ppm dan 150 ppm. Stimulan alami ekstrak umbi bawang merah dibuat dengan cara mengupas kulit umbi bawang merah dan dibersihkan, dihaluskan sampai berbentuk bubur. Bubur disaring sehingga didapatkan ekstrak bawang merah, kemudian diencerkan dengan aquades sampai konsentrasi mencapai $40 \%$ dan $60 \%$. Stimulan alami dari urin sapi dibuat dengan mengencerkan urin sapi dengan aquades sampai konsentrasi $15 \%$ dan $25 \%$ yang terlebih dahulu sudah difermentasi selama seminggu. Larutan dibuat sebanyak tiga kali ulangan. Pemberian auksin pada setek dilakukan dengan cara mencelupkan secara cepat ke larutan selama 15 detik.

Penanaman setek dilakukan dengan cara ditugal. Sebelum penanaman terlebih dahulu dibuat lubang tanam sedalam $3 \mathrm{~cm}$ agar setek tidak rusak dan stimulan tidak terbuang percuma karena gesekan dengan media. Setelah itu setek segera ditanam bersamaan dengan pemberian furadan. Media disiram dengan sprayer secukupnya agar setek tetap segar dan media tetap cukup air untuk mendorong pertumbuhan setek. Setelah calon cabang baru muncul dilakukan pemasangan label dengan mengambil tiga sampel calon cabang pada masing-masing setek.
Pemeliharaan dilakukan untuk memberikan kondisi yang optimum pada setek. Pemeliharaan yang dilakukan berupa penyiraman, penyiangan gulma, dan pengendalian hama dan penyakit. Pembibitan torbangun dipelihara secara intensif dengan penyiraman setiap hari. Penyiangan dilakukan setiap satu minggu sekali untuk mengurangi gulma. Pengendalian hama dan penyakit pada setek pucuk torbangun dilakukan secara manual.

Pengamatan pada penelitian ini dilakukan sejak 1-12 Minggu Setelah Tanam (MST). Peubah yang diamati meliputi persentase setek hidup (\%) pada akhir pengamatan, tinggi setek $(\mathrm{cm})$, jumlah daun per setek, jumlah cabang, jumlah daun per cabang, panjang cabang $(\mathrm{cm})$, jumlah akar, panjang akar (cm), bobot segar akar (g), bobot segar brangkasan (g), bobot kering akar (g), bobot kering brangkasan $(\mathrm{g})$.

\section{HASIL DAN PEMBAHASAN}

\section{Kondisi Umum}

Penelitian dilakukan dari bulan April 2015 sampai Juli 2015. Menurut BMKG Dramaga (2015) tercatat lama penyinaran matahari mengalami perubahan yang ekstrim dari bulan April sebesar 43.3\% terus meningkat sampai $90 \%$ pada bulan Juli. Demikian pula data curah hujan mengalami penurunan yang ekstrim dari $206.1 \mathrm{~mm}$ pada bulan April, kemudian mengalami penurunan sampai 90.2 $\mathrm{mm}$ pada bulan Juni, hingga $1.6 \mathrm{~mm}$ pada bulan Juli. Rumetor (2008) menyatakan bahwa tanaman torbangun tidak tahan terhadap curah hujan dan penyinaran yang berlebihan karena tanaman mudah busuk atau layu. Tanaman torbangun akan tumbuh baik apabila terdapat tanaman pelindung, maka dalam penelitian ini digunakan paranet dengan intensitas naungan $60 \%$ untuk mengurangi intensitas cahaya yang berlebihan selama penelitian berlangsung.

Hama yang menyerang setek pucuk torbangun ketika dilahan yaitu hama nematode Meloidogyne incognit yang menyebabkan pembengkakan pada akar, serta belalang (Oxya sp.) yang menyebabkan daundaun berlubang. Hama lain yang mengganggu pertumbuhan setek pucuk torbangun yaitu walang sangit (Leptocorisa acuta), kumbang (Epilachna admirabilis), dan ulat (Crocidolomia pavovana). Gulma yang tumbuh pada lahan penanaman yaitu golongan rumput-rumputan, teki, dan daun lebar. Pengendalian yang dilakukan untuk mengatasi serangan hama dan penyakit hanya dilakukan secara manual karena serangan yang ditimbulkan 
belum mencapai tahap yang merugikan.

Serangan cendawan mengakibatkan setek pucuk torbangun mengalami busuk batang sebesar $3.57 \%$. Royal Horticulture Society (2008) mengungkapkan bahwa penyakit yang menyerang Coleus adalah Downy mildew. Penyakit Downy mildew ditunjukkan oleh bercak-bercak coklat pada daun. Sebagian gejala muncul tidak hanya pada daun sehingga sulit untuk mengetahui serangan dan melakukan pengendalian hama penyakit. Organisme yang menyebabkan penyakit Downy mildew adalah Peronospora sp.

Persentase Setek Hidup
Persentase setek hidup diamati pada akhir pengamatan yaitu pada minggu ke-12 setelah tanam. Seluruh setek pucuk torbangun yang diberikan stimulan sintetik konsentrasi 100 ppm dan $150 \mathrm{ppm}$ mampu bertahan hidup 100\% sampai akhir pengamatan. Pemberian stimulan alami urin sapi $15 \%$, urin sapi $25 \%$, ekstrak bawang merah $40 \%$, dan ekstrak bawang merah $60 \%$ menghasilkan persentase setek hidup lebih rendah yaitu $95.83 \%$. Persentase setek sebesar $91.67 \%$ dihasilkan perlakuan tanpa pemberian stimulan (Gambar 1). Berdasarkan peubah persentase setek hidup, aplikasi stimulan sintetik dan alami tidak mempengaruhi jumlah setek hidup yang dihasilkan.

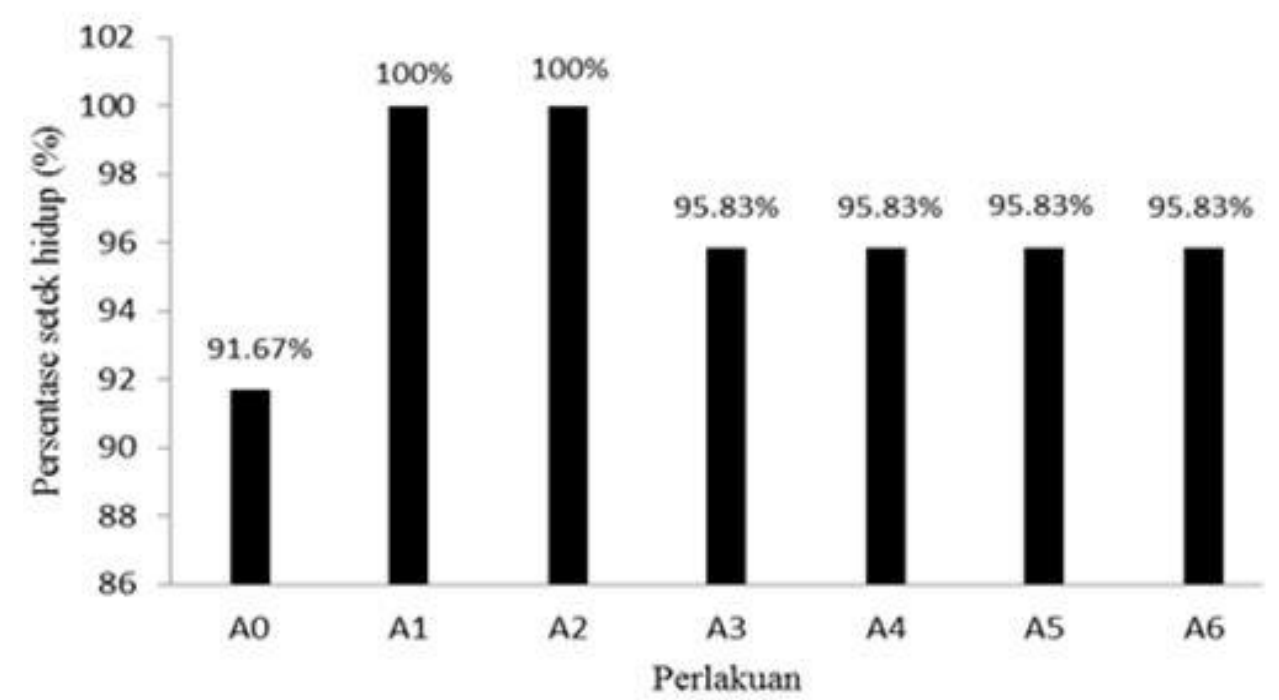

Gambar 1 Persentase hidup setek pucuk torbangun pada 12 MST.

Kematian setek pucuk torbangun sebagian besar diakibatkan oleh serangan cendawan yang menyerang batang setek. Busuk batang ditunjukkan oleh pangkal setek berwarna hitam, lunak, batang rebah, batang bagian dalam berwarna hitam, dan tidak berisi jaringan lagi. Selain itu terdapat gejala sekunder dari adanya serangan cendawan yaitu bagian daun seperti mengering dan berwarna coklat kehitaman.

Muhammad (2002) menyatakan bahwa urin sapi mengandung amonia $\left(\mathrm{NH}^{3}\right) 2.49 \mathrm{mg} \mathrm{L}^{-1}$, Nitrat $\left(\mathrm{NO}^{3}\right) 12.97 \mathrm{mg} \mathrm{L}^{-1}$ dan Nitrit $\left(\mathrm{NO}^{2}\right) 0.78$ $\mathrm{mg} \mathrm{\textrm {L } ^ { - 1 }}$ yang tergolong tinggi. Zat-zat yang terkandung dalam urin sapi dapat bersifat toksik bagi tanaman sehingga diduga dapat menurunkan persentase setek hidup, namun dalam penelitian ini dilakukan fermentasi urin sapi selama satu minggu sebelum aplikasi untuk menurunkan kadar amonia, nitrat, dan nitrit. Selain itu fermentasi urin sapi bermanfaat untuk meningkatkan kadar N, P, dan K didalam urin sapi. Persentase setek hidup yang rendah juga dihasilkan perlakuan stimulan ekstrak bawang merah. Berbeda dengan hasil penelitian Siskawati et al. (2013) menyatakan bahwa aplikasi ekstrak bawang merah $40 \%$ dan 60\% mampu meningkatkan pertumbuhan akar jarak pagar. Inisiasi dan pertumbuhan akar merupakan hal utama yang menentukan keberhasilan setek, sehingga pertumbuhan akar akan menentukan jumlah setek hidup yang dihasilkan.

Stimulan sintetik menghasilkan persentase hidup setek pucuk torbangun sebesar $100 \%$. Berdasarkan percobaan pendahuluan, perlakuan tanpa aplikasi stimulan, stimulan sintetik $100 \mathrm{ppm}$, stimulan sintetik $150 \mathrm{ppm}$, urin sapi $15 \%$, urin sapi $25 \%$, ekstrak bawang merah $40 \%$, dan ekstrak bawang merah $60 \%$ menghasilkan jumlah akar berturut-turut 1-2 akar, 7-12 akar, 10-15 akar, 1-3 akar, 2-5 akar, 3-6 akar, 7-9 akar. Perlakuan stimulan sintetik menghasilkan jumlah akar lebih besar dibandingkan perlakuan lainnya. Hal ini menyebabkan aplikasi stimulan sintetik menghasilkan setek pucuk torbangun yang lebih vigor.

\section{Tinggi Setek}

Data tinggi setek pucuk torbangun selama 12 MST disajikan pada Gambar 2. 
Pengaruh stimulan terhadap peubah tinggi setek pucuk torbangun menunjukkan hasil yang tidak nyata. Tinggi setek pucuk torbangun saat berumur 2 MST dan 3 MST kurang dari $10 \mathrm{~cm}$ yaitu berturut-turut sebesar $8.12 \mathrm{~cm}$ dan $8.99 \mathrm{~cm}$. Tinggi setek pucuk torbangun pada 4 MST meningkat menjadi $10.01 \mathrm{~cm}$, selanjutnya pada 5 MST dan 6 MST tinggi setek pucuk torbangun yang dihasilkan yaitu $10.56 \mathrm{~cm}$ dan $10.79 \mathrm{~cm}$. Setek pucuk torbangun saat berumur 7-11 MST menghasilkan tinggi setek berkisar antara $11 \mathrm{~cm}$ $11.7 \mathrm{~cm}$, sedangkan pada akhir pengamatan yaitu pada 12 MST tinggi setek pucuk torbangun yang dihasilkan tidak jauh berbeda dengan tinggi setek pucuk torbangun pada minggu sebelumnya yaitu sebesar $11.80 \mathrm{~cm}$.

Tinggi setek pucuk torbangun yang dihasilkan bertambah seiring dengan lamanya waktu pengamatan namun tidak signifikan (Gambar 2). Hasil penelitian Putri dan Sudianta (2009) menunjukkan bahwa tinggi setek pucuk Rhododendron javanicum Benn. menggunakan stimulan sintetik serupa, dengan konsentrasi 100 ppm dan 150 ppm bertambah seiring dengan lama waktu pengamatan, namun secara statistik tidak nyata.

Karimah et al. (2013) menambahkan bahwa perlakuan rimpang temulawak dengan urin sapi konsentrasi $25 \%, 50 \%$, dan $75 \%$ tidak menunjukkan pengaruh nyata pada peubah tinggi setek. Khair et al. (2013) menyatakan perlakuan setek melati putih pada ekstrak bawang merah 5 cc $\mathrm{L}^{-1}, 10 \mathrm{cc} \mathrm{L}^{-1}$, dan $15 \mathrm{cc} \mathrm{L}^{-1}$ memberikan pengaruh yang tidak nyata pada peubah tinggi setek.

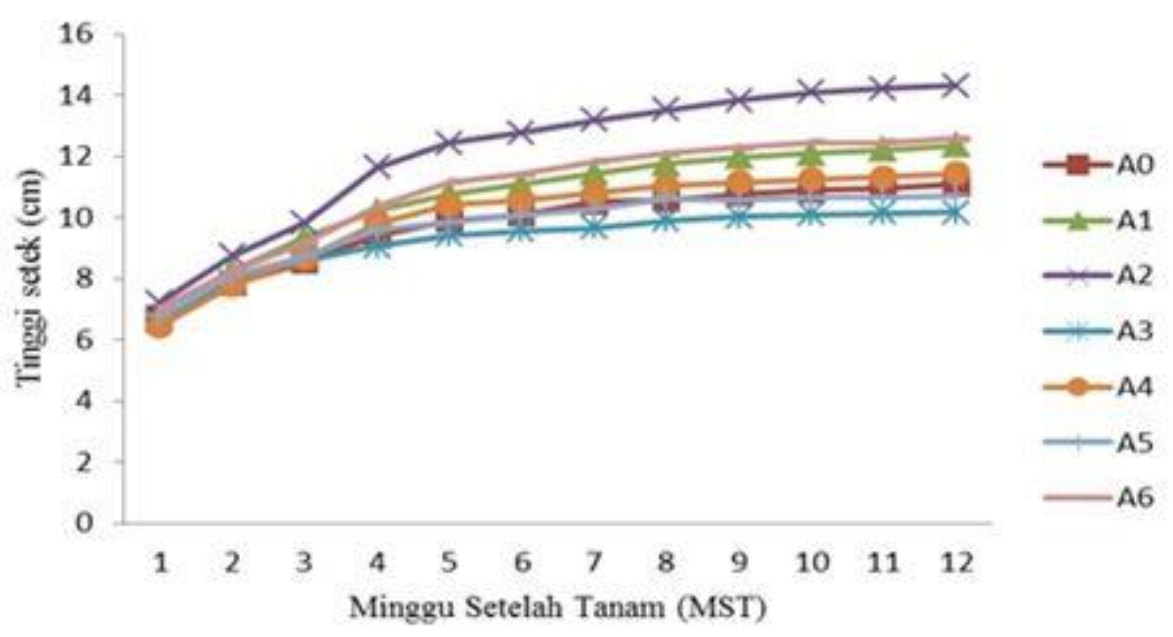

Gambar 2 Tinggi setek pucuk torbangun pada 1-12 MST

Bahan setek yang digunakan dalam penelitian ini berasal dari pucuk yang merupakan jaringan muda dan meristematik. Hasil penelitian Hossain dan Bhuiyan (2006) pada jambu biji (Psidium guajava Linn), menggunakan bahan setek muda meningkatkan pertumbuhan batang setek. Bahan setek muda memiliki juvenilitas tinggi serta kandungan auksin dan sitokinin yang tinggi. Kandungan auksin dan sitokinin endogen yang tinggi diduga menyebabkan pemberian stimulan eksogen tidak efektif meningkatkan tinggi setek.

\section{Jumlah Daun}

Berdasarkan hasil uji $\mathrm{F}$ pada taraf $5 \%$, peubah jumlah daun per setek maupun jumlah daun per cabang secara statistik tidak dipengaruhi secara nyata oleh aplikasi stimulan. Data jumlah daun per setek pucuk torbangun dapat dilihat pada Tabel 1. Jumlah daun per setek pucuk torbangun yang dihasilkan saat 2 MST yaitu 8.90, sedangkan pada 3 MST mengalami peningkatan mencapai 17.66. Setek pucu torbangun saat 4-7 MST berturut-turut menghasilkan jumlah daun sebanyak 29.09, 35.16, 37.70 , dan 36.81. Jumlah daun per setek pucuk torbangun yang dihasilkan pada 8-12 MST berfluktuatif berturut-turut sebesar 37.24, 37.07, 32.52, 32.98, dan 34.38. Penurunan jumlah daun per setek pucuk torbangun yang besar terjadi pada 10 MST yaitu 4.55. 
Tabel 1 Jumlah daun per setek pucuk torbangun pada 1-12 MST dengan berbagai perlakuan stimulan

\begin{tabular}{llllllllll}
\hline MST & A0 & A1 & A2 & A3 & A4 & A5 & A6 & Rata-rata & KK(\%) \\
\hline 1 & 4.12 & 3.96 & 4.08 & 3.96 & 3.96 & 3.96 & 4 & $4.01^{\text {tn }}$ & 4.15 \\
2 & 9.46 & 7.67 & 10.29 & 8.54 & 9.25 & 8.35 & 8.75 & $8.90^{\text {tn }}$ & 17.11 \\
3 & 17.54 & 18.08 & 18.75 & 16.58 & 18.42 & 17.47 & 16.75 & $17.66^{\text {tn }}$ & 13.31 \\
4 & 29.54 & 30.85 & 31.71 & 26.92 & 27.96 & 27.01 & 29.63 & $29.09^{\text {tn }}$ & 13.98 \\
5 & 35.29 & 36.6 & 37.42 & 32.88 & 33.68 & 33.77 & 36.46 & $35.16^{\text {tn }}$ & 14.5 \\
6 & 37.58 & 39.64 & 39.21 & 35.54 & 38.52 & 36.11 & 37.29 & $37.70^{\text {tn }}$ & 17.63 \\
7 & 37.54 & 38.89 & 39.29 & 32.33 & 35.79 & 36.52 & 37.34 & $36.81^{\text {tn }}$ & 16.14 \\
8 & 36.71 & 38.99 & 39.71 & 34.44 & 37.86 & 35.78 & 37.18 & $37.24^{\text {tn }}$ & 16.96 \\
9 & 35.37 & 38.18 & 39.04 & 33.61 & 37.81 & 37.19 & 38.27 & $37.07^{\text {tn }}$ & 15.54 \\
10 & 31.58 & 33.95 & 33.54 & 30.4 & 33.27 & 32.01 & 32.86 & $32.52^{\text {tn }}$ & 16.46 \\
11 & 32.38 & 33.64 & 34.79 & 29.63 & 34.06 & 33.56 & 32.79 & $32.98^{\text {tn }}$ & 17.32 \\
12 & 33.71 & 36.01 & 36.46 & 31.78 & 35.27 & 33.16 & 34.26 & $34.38^{\text {tn }}$ & 15.78 \\
\hline
\end{tabular}

Keterangan: ${ }^{\text {tn }}=$ tidak nyata berdasarkan uji F pada taraf 5\%. A0 = tanpa perlakuan stimulan; A1 = stimulan sintetik $100 \mathrm{ppm} ; \mathrm{A} 2=$ stimulan sintetik $150 \mathrm{ppm}$; A3 = stimulan alami urin sapi 15\%; A4 = stimulan alami urin sapi 25\%; A5 = stimulan alami ekstrak bawang merah 40\%; A6 = stimulan alami ekstrak bawang merah 60\%; KK = koefisien keragaman

Tabel 2 menyajikan nilai jumlah daun per cabang setek pucuk torbangun. Data jumlah daun per cabang setek pucuk torbangun mulai dihitung saat 3 MST karena daun pada cabang muncul pertama kali saat 2 MST dan memiliki ukuran daun $\leq 1 \mathrm{~cm}$. Setek pucuk torbangun menghasilkan jumlah daun per cabang kurang dari sembilan hingga akhir pengamatan. Jumlah daun per cabang yang dihasilkan setek pucuk torbangun pada 36 MST berturut-turut sebesar 4.57, 6.29, 7.75, dan 8.43. Jumlah daun per cabang maksimal dihasilkan pada 8 MST, jumlah daun per cabang yang dihasilkan pada 9 MST tidak mengalami pertambahan, kemudian mengalami penurunan pada 10 MST. Jumlah daun per cabang setek pucuk torbangun meningkat kembali pada 11 MST dan 12 MST yaitu mencapai 7.92 dan 8.22.

Tabel 2 Jumlah daun per cabang setek pucuk torbangun pada 1-12 MST dengan berbagai perlakuan stimulan

\begin{tabular}{llllllllll}
\hline MST & A0 & A1 & A2 & A3 & A4 & A5 & A6 & Rata-rata & KK $(\%)$ \\
\hline 1 & - & - & - & - & - & - & - & - & - \\
2 & - & - & - & - & - & - & - & - & - \\
3 & 4.28 & 4.97 & 4.51 & 4.65 & 4.34 & 4.58 & 4.68 & $4.57^{\text {tn }}$ & 14.27 \\
4 & 6.1 & 6.67 & 6.29 & 6.46 & 5.93 & 6.02 & 6.55 & $6.29^{\text {tn }}$ & 13.73 \\
5 & 7.51 & 7.88 & 7.82 & 7.71 & 7.49 & 7.99 & 7.86 & $7.75^{\text {tn }}$ & 13.89 \\
6 & 8.05 & 9.07 & 8.26 & 8.08 & 7.99 & 9.11 & 8.45 & $8.43^{\text {tn }}$ & 13.32 \\
7 & 7.93 & 8.97 & 8.58 & 8.22 & 8.18 & 9.43 & 8.42 & $8.53^{\text {tn }}$ & 13.4 \\
8 & 8.07 & 9.45 & 8.57 & 8.36 & 8.61 & 9.95 & 8.2 & $8.74^{\text {tn }}$ & 14.14 \\
9 & 7.84 & 9.49 & 8.2 & 8.42 & 8.48 & 10.17 & 8.61 & $8.74^{\text {tn }}$ & 15.29 \\
10 & 6.89 & 8.08 & 7.56 & 7.42 & 7.6 & 9 & 7.68 & $7.75^{\text {tn }}$ & 13.47 \\
11 & 7.36 & 8.25 & 7.91 & 7.54 & 7.46 & 9.28 & 7.66 & $7.92^{\text {tn }}$ & 15.15 \\
12 & 7.6 & 8.68 & 7.86 & 8.05 & 7.82 & 9.42 & 8.12 & $8.22^{\text {tn }}$ & 13.77 \\
\hline
\end{tabular}

Keterangan: ${ }^{\mathrm{tn}}=$ tidak nyata berdasarkan uji $\mathrm{F}$ pada taraf $5 \%$. A0 = tanpa perlakuan stimulan; $\mathrm{A} 1=$ stimulan sintetik $100 \mathrm{ppm} ; \mathrm{A} 2=$ stimulan sintetik $150 \mathrm{ppm}$; A3 = stimulan alami urin sapi 15\%; A4 = stimulan alami urin sapi $25 \%$; A5 = stimulan alami ekstrak bawang merah 40\%; A6 = stimulan alami ekstrak bawang merah 60\%; KK= koefisien keragaman

Jumlah daun per setek pucuk torbangun maupun jumlah daun per cabang sama-sama mengalami penurunan pada 10 MST. Penurunan jumlah daun setek pucuk torbangun pada 10 MST dihasilkan karena adanya pengguguran daun dalam jumlah besar. Daun yang gugur mengering dan berwarna kuning kecoklatan. Hal ini diduga disebabkan oleh pengaruh suhu tempat penelitian yang tinggi dengan suhu maksimum mencapai $31.5^{\circ} \mathrm{C}$.

Jumlah daun merupakan hasil dari pertumbuhan dan perkembangan sel yang dipengaruhi oleh suplai unsur hara yang diberikan akar untuk metabolisme dan sintesis protein. Aktifitas auksin dipengaruhi oleh faktor lingkungan. Suhu tinggi menyebabkan setek kekurangan air, mengering, kemudian menggugurkan daunnya. Kebutuhan air yang tidak tercukupi akan menurunkan aktivitas fotosintesis. Karbohidrat bersama dengan auksin berperan dalam pembelahan, pemanjangan, dan pembesaran sel. Defisiensi karbohidrat dapat terjadi karena berkurangnya tingkat kelangsungan fotosintesis akibat berkurangnya jumlah daun dan sedikitnya ketersediaan air, sehingga menghambat pembentukan organ baru (Lakitan 2006).

Pertambahan Panjang Cabang dan Jumlah Cabang Waktu muncul cabang pertama kali terjadi saat 2 MST, namun cabang tersebut masih 
belum dapat dihitung jumlahnya maupun diukur panjangnya karena dalam penelitian ini cabang yang dihitung dan diukur yaitu cabang yang sudah memiliki panjang $\geq 2 \mathrm{~cm}$. Berdasarkan hasil analisis uji $\mathrm{F}$, jumlah cabang maupun pertambahan panjang cabang tidak dipengaruhi secara nyata oleh aplikasi stimulan. Hal ini sesuai dengan penelitian yang dilakukan Karimah et al. (2013) pada rimpang temulawak (Curcuma xanthorriza Roxb.) memperoleh hasil yang tidak berpengaruh nyata pada nilai daya bercabang dengan perlakuan perendaman dalam urin sapi dengan konsentrasi $25 \%, 50 \%$, dan $75 \%$.

Terlihat dari grafik yang meningkat tiap minggunya, nilai panjang cabang bertambah seiring dengan lamanya waktu pengamatan (Gambar 3). Budianto et al. (2013) dalam penelitiannya menyatakan perlakuan pemberian stimulan IBA dan NAA pada setek sirih merah menghasilkan panjang cabang setek sirih merah terus mengalami peningkatan tiap minggunya, yaitu sebesar 3 kali lipat pada 4 MST dan 6 MST serta 2 kali lipat pada 8 MST sampai 12 MST.

Nilai pertambahan panjang cabang setek pucuk torbangun dalam penelitian ini maksimal dihasilkan saat 4 MST, kemudian mengalami penurunan yang besar pada 10 MST. Setek pucuk torbangun menghasilkan pertambahan panjang cabang yang rendah pada akhir pengamatan yaitu 11 MST dan 12 MST (Gambar 3). Penurunan pertambahan panjang cabang setek pucuk torbangun yang besar pada 10 MST diakibatkan kondisi suhu lingkungan yang tinggi dengan suhu maksimum mencapai $31.5{ }^{0} \mathrm{C}$ serta curah hujan yang sangat rendah yaitu $90.2 \mathrm{~mm}$ bulan $^{-1}$. Hal ini mengakibatkan kurangnya ketersediaan air untuk mendukung pertumbuhan cabang setek pucuk torbangun.

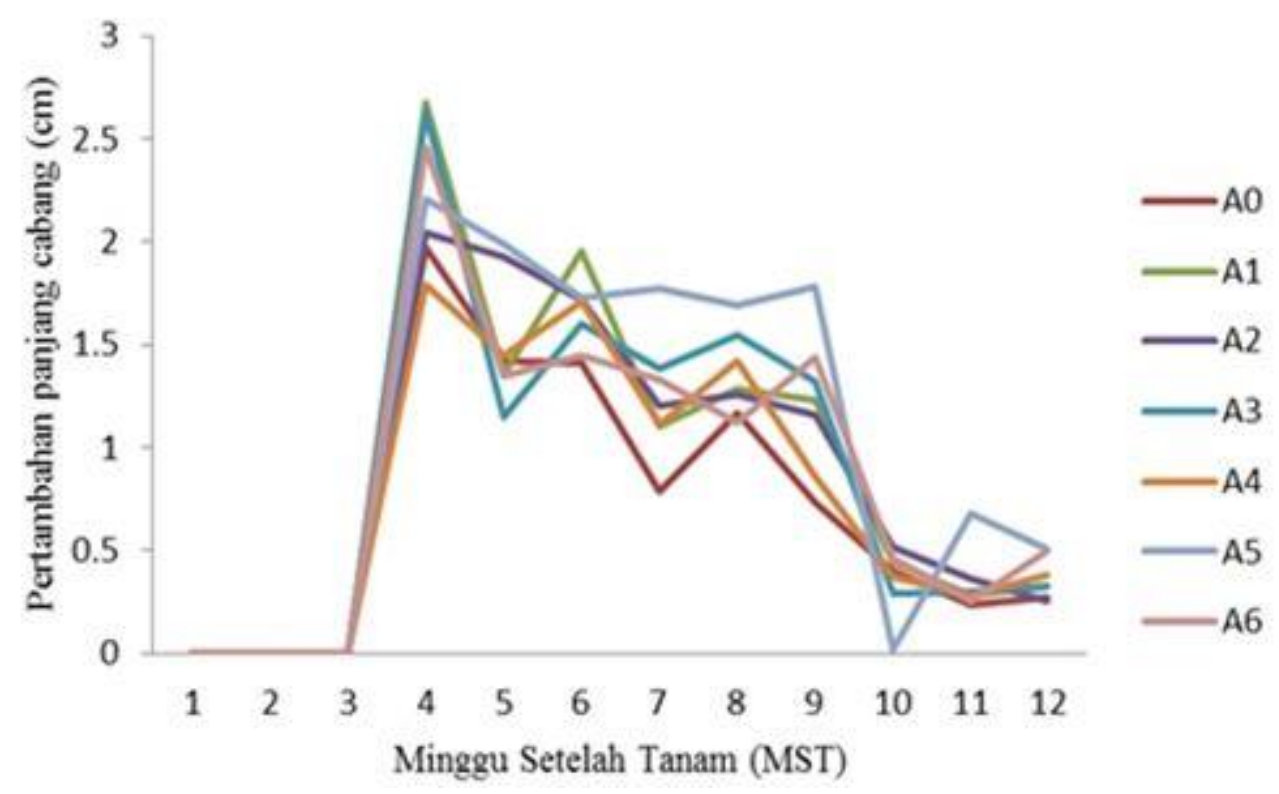

Gambar 3 Pertambahan panjang cabang setek pucuk torbangun

Data jumlah cabang dapat dilihat pada Tabel 3. Nilai jumlah cabang setek pucuk torbangun yang dihasilkan sampai akhir pengamatan kurang dari empat. Setek pucuk torbangun pada 3-5 MST menghasilkan jumlah cabang kurang dari tiga yaitu berturut-turut sebesar $1.95,2.30$, dan 2.85, sedangkan pada 6-12
MST jumlah cabang setek pucuk torbangun berkisar antara 3-4 yaitu berturut-turut sebesar 3.18, 3.34, 3.48, 3.83, 3.86, 3.87, dan 3.91. Jumlah cabang setek pucuk torbangun rendah diakibatkan oleh kondisi lingkungan suboptimum yang terjadi selama penelitian berlangsung, terutama pada dua bulan terakhir masa penelitian. 
Tabel 3 Jumlah cabang setek pucuk torbangun pada 1-12 MST dengan berbagai perlakuan stimulan

\begin{tabular}{llllllllll}
\hline MST & A0 & A1 & A2 & A3 & A4 & A5 & A6 & Rata-rata & KK (\%) \\
\hline 1 & - & - & - & - & - & - & - & - & - \\
2 & - & - & - & - & - & - & - & - & - \\
3 & 1.92 & 2 & 1.89 & 1.77 & 2.06 & 2.21 & 1.82 & $1.95^{\text {tn }}$ & 17.6 \\
4 & 2.14 & 2.13 & 2.35 & 2.5 & 2.24 & 2.35 & 2.38 & $2.30^{\text {tn }}$ & 20.61 \\
5 & 2.4 & 2.81 & 2.88 & 2.98 & 3 & 2.96 & 2.92 & $2.85^{\text {tn }}$ & 22.88 \\
6 & 2.77 & 3.01 & 3.29 & 3.42 & 3.33 & 3.29 & 3.17 & $3.18^{\text {tn }}$ & 24.98 \\
7 & 2.95 & 3.26 & 3.38 & 3.71 & 3.51 & 3.38 & 3.21 & $3.34^{\text {tn }}$ & 22.19 \\
8 & 2.99 & 3.41 & 3.42 & 3.72 & 3.64 & 3.42 & 3.75 & $3.48^{\text {tn }}$ & 23.29 \\
9 & 3.39 & 3.79 & 3.75 & 4.27 & 3.98 & 3.83 & 3.82 & $3.83^{\text {tn }}$ & 16.11 \\
10 & 3.43 & 3.79 & 3.79 & 4.4 & 3.89 & 3.87 & 3.86 & $3.86^{\text {tn }}$ & 15.57 \\
11 & 3.43 & 3.79 & 3.75 & 4.4 & 3.89 & 4 & 3.86 & $3.87^{\text {tn }}$ & 15.44 \\
12 & 3.61 & 3.79 & 3.88 & 4.32 & 3.85 & 4.04 & 3.9 & $3.91^{\text {tn }}$ & 15.22 \\
\hline
\end{tabular}

Keterangan: ${ }^{\text {tn }}=$ tidak nyata berdasarkan uji F pada taraf 5\%. A0 = kontrol; A1 = stimulan sintetik 100 ppm; A2 = stimulan sintetik 150 ppm; A3 = stimulan alami urin sapi 15\%; A4 = stimulan alami urin sapi 25\%; A5 = stimulan alami ekstrak bawang merah 40\%; A6 = stimulan alami ekstrak bawang merah 60\%; KK= koefisien keragaman.

Panjang dan jumlah cabang merupakan salah satu kriteria yang menentukan kualitas setek. Semakin panjang dan banyak cabang yang dihasilkan semakin banyak bahan yang diperoleh untuk perbanyakan selanjutnya. Stimulan alami memerlukan proses yang lebih lama untuk dapat diabsorpsi secara sempurna oleh tanaman. Stimulan alami berupa urin sapi dan ekstrak bawang merah diduga belum terserap sempurna oleh setek pucuk torbangun sampai akhir pengamatan yaitu $12 \mathrm{MST}$, sementara proses pertumbuhan tanaman sudah berlangsung. Hal ini diduga menjadi penyebab peubah panjang dan jumlah cabang tidak dipengaruhi secara nyata oleh aplikasi stimulan karena penelitian dilakukan sampai setek pucuk torbangun tumbuh sebagai bibit (12 MST) dan belum menjadi tanaman dewasa.

\section{Panjang dan Jumlah Akar}

Berdasarkan hasil uji $\mathrm{F}$ pada taraf $5 \%$, panjang akar dan jumlah akar tidak dipengaruhi secara nyata oleh aplikasi stimulan. Hal ini diduga disebabkan setek pucuk torbangun yang direndam stimulan selama 15 detik belum optimal menyerap larutan stimulan. Setek torbangun merupakan jenis setek herbaceous sehingga jumlah larutan yang diabsorbsi tergantung pada jumlah air yang diabsorbsi dan ditentukan oleh lamanya kontak setek dengan larutan. Wiratri (2005) dalam penelitiannya menyatakan bahwa kombinasi setek pucuk Gmelina (Gmelina arborea Linn.) dengan

cara perendaman dalam larutan stimulan sintetik serupa, dengan konsentrasi 100 ppm selama 24 jam menunjukkan hasil paling baik pada peubah persentase setek berakar. Menurut McMahon et al. (2007) setek batang pembiakan tanaman herbaceous seperti Coleus,

Carnation dan Aglonema tergolong setek yang mudah berakar. Sifat setek torbangun yang mudah berakar juga diduga menjadi penyebab tidak adanya pengaruh dari aplikasi stimulan terhadap peubah panjang dan jumlah akar.

Pengaruh aplikasi stimulan terhadap jumlah akar dan panjang akar terdapat pada Tabel 4. Perlakuan tanpa aplikasi stimulan menghasilkan panjang akar yaitu $23.42 \mathrm{~cm}$. Panjang akar yang dihasilkan perlakuan stimulan sintetik $150 \mathrm{ppm}$ yaitu $26.98 \mathrm{~cm}$, lebih baik dibandingkan tanpa aplikasi stimulan. Hal ini sesuai dengan penelitian Sudomo et al. (2013) menyatakan bahwa aplikasi stimulan sintetik sejenis, konsentrasi 150 ppm pada setek pucuk manglid menghasilkan panjang akar sebesar $8.85 \mathrm{~cm}$ dan jumlah akar sebesar 6.75 , lebih besar dibandingkan tanpa aplikasi stimulan.

Jumlah akar yang dihasilkan aplikasi stimulan sintetik $150 \mathrm{ppm}$ yaitu $23.99 \mathrm{~cm}$, sedangkan jumlah akar tanpa aplikasi stimulan yaitu $21.62 \mathrm{~cm}$ (Tabel 4). Sesuai dengan Kusumah et al. (2012) dalam penelitiannya menyatakan bahwa jumlah akar lebih banyak dihasilkan $D$. cinereum dengan perlakuan stimulan sintetik serupa, dengan konsentrasi 150 ppm dibandingkan tanpa perlakuan stimulan. 
Tabel 4. Pengaruh perlakuan stimulan terhadap panjang akar dan jumlah akar setek pucuk torbangun

\begin{tabular}{|c|c|c|}
\hline \multirow{2}{*}{$\begin{array}{l}\text { Perlakuan Stimulasi } \\
\text { Pertumbuhan Setek }\end{array}$} & $\begin{array}{l}\text { Panjang } \\
\text { Akar }\end{array}$ & $\begin{array}{l}\text { Jumlah } \\
\text { Akar }\end{array}$ \\
\hline & \multicolumn{2}{|c|}{-------cm--------- } \\
\hline Tanpa perlakuan stimulan & 23.42 & 21.62 \\
\hline Stimulan sintetik $100 \mathrm{ppm}$ & 26.17 & 22.8 \\
\hline Stimulan sintetik $150 \mathrm{ppm}$ & 26.98 & 23.99 \\
\hline Urin sapi $15 \%$ & 26.23 & 22.17 \\
\hline Urin sapi $25 \%$ & 26.68 & 23.08 \\
\hline Ekstrak bawang merah $40 \%$ & 24.18 & 23.02 \\
\hline Ekstrak bawang merah $60 \%$ & 25.21 & 23.28 \\
\hline $\mathrm{KK}(\%)$ & 10.39 & 10.27 \\
\hline Respon & tn & tn \\
\hline
\end{tabular}

Faktor lain yang mempengaruhi kondisi perakaran setek yaitu media perakaran. Media tanah dan pupuk kandang dengan perbandingan 1:1 diduga kurang optimal digunakan sebagai media pertumbuhan setek pucuk torbangun. Akar yang dimiliki setek pucuk torbangun merupakan akar serabut dan kurang kuat perakarannya sehingga media tanam dengan pori-pori besar dibutuhkan setek pucuk torbangun untuk memudahkan pertumbuhan akar, seperti media pasir. Penelitian Mashudi (2013) menyatakan bahwa persen berakar setek pucuk pulai darat tertinggi dihasilkan oleh media pasir (M1) yaitu sebesar $60.89 \%$. Hasil ini sejalan dengan penelitian Mashudi (2011), persen berakar setek pucuk pulai darat terbaik dari trubusan umur lima bulan adalah media pasir. Penelitian lain menunjukkan bahwa media pasir + kompos merupakan media terbaik untuk perakaran setek pucuk pulai gading ( (L.) R.Br.) (Mahfudz 2003). Jumlah akar terbanyak pada setek pucuk Eucalyptus pellita $\mathrm{F}$. Muel juga dihasilkan perlakuan dengan media pasir (Prastyono 2003).

\section{Bobot Segar dan Bobot Kering Akar serta Brangkasan}

Hasil analisis uji $\mathrm{F}$ menunjukkan tidak adanya pengaruh yang nyata pada perlakuan aplikasi stimulan terhadap peubah bobot segar dan kering akar serta bobot segar dan kering brangkasan. Hal serupa dinyatakan Khair et al. (2013) dalam penelitiannya pada setek melati putih (Jasminum sambac L.) memberikan hasil yang tidak dipengaruhi secara nyata oleh aplikasi ekstrak bawang merah terhadap peubah berat basah akar dan berat kering akar. Data pengaruh bahan stimulan terhadap bobot segar serta bobot kering akar dan brangkasan disajikan pada Tabel 5. Perlakuan tanpa aplikasi stimulan, stimulan sintetik $100 \mathrm{ppm}$, stimulan sintetik 150 ppm, urin sapi $15 \%$, urin sapi $25 \%$, ekstrak bawang merah $40 \%$, dan ekstrak bawang merah $60 \%$ berturut-turut menghasilkan bobot segar akar yaitu $18.47 \mathrm{~g}$ per tanaman, $22.57 \mathrm{~g}$ per tanaman, $26.27 \mathrm{~g}$ per tanaman, $20.73 \mathrm{~g}$ per tanaman, $21.60 \mathrm{~g}$ per tanaman, $22.00 \mathrm{~g}$ per tanaman, dan $20.43 \mathrm{~g}$ per tanaman. Bobot kering akar dengan perlakuan tanpa aplikasi stimulan, stimulan sintetik $100 \mathrm{ppm}$, stimulan sintetik 150 ppm, urin sapi $15 \%$, urin sapi $25 \%$, ekstrak bawang merah $40 \%$, dan ekstrak bawang merah $60 \%$ berturut-turut menghasilkan bobot kering akar yaitu $4.37 \mathrm{~g}$ per tanaman, $4.54 \mathrm{~g}$ per tanaman, $5.92 \mathrm{~g}$ per tanaman, $4.38 \mathrm{~g}$ per tanaman, $5.47 \mathrm{~g}$ per tanaman, $5.03 \mathrm{~g}$ per tanaman, dan $5.40 \mathrm{~g}$ per tanaman (Tabel 5).

Bobot segar brangkasan yang dihasilkan setek pucuk torbangun dengan perlakuan tanpa aplikasi stimulan, stimulan sintetik 100 ppm, stimulan sintetik $150 \mathrm{ppm}$, urin sapi $15 \%$, urin sapi $25 \%$, ekstrak bawang merah $40 \%$, dan ekstrak bawang merah $60 \%$ berturut-turut yaitu $177.63 \mathrm{~g}$ per tanaman, $195.13 \mathrm{~g}$ per tanaman, $210.90 \mathrm{~g}$ per tanaman, $190.93 \mathrm{~g}$ per tanaman, $199.93 \mathrm{~g}$ per tanaman, $191.90 \mathrm{~g}$ per tanaman, dan 202.40 g per tanaman. Bobot kering brangkasan yang dihasilkan perlakuan tanpa aplikasi stimulan, stimulan sintetik $100 \mathrm{ppm}$, stimulan sintetik 150 ppm, urin sapi $15 \%$, urin sapi $25 \%$, ekstrak bawang merah $40 \%$, dan ekstrak bawang merah $60 \%$ berturut-turut yaitu $18.02 \mathrm{~g}$ per tanaman, $23.31 \mathrm{~g}$ per tanaman, $23.87 \mathrm{~g}$ per tanaman, $20.06 \mathrm{~g}$ per tanaman, $20.14 \mathrm{~g}$ per tanaman, 20.30 g per tanaman, dan 23.22 g per tanaman (Tabel 5). 
Tabel 5 Pengaruh perlakuan stimulan terhadap bobot segar serta bobot kering akar dan brangkasan

\begin{tabular}{|c|c|c|c|c|}
\hline Perlakuan stimulasi pertumbuhan setek & $\begin{array}{l}\text { Bobot } \\
\text { segar } \\
\text { akar } \\
\end{array}$ & $\begin{array}{l}\text { Bobot } \\
\text { kering } \\
\text { akar }\end{array}$ & $\begin{array}{l}\text { Bobot segar } \\
\text { brangkasan }\end{array}$ & $\begin{array}{l}\text { Bobot kering } \\
\text { brangkasan }\end{array}$ \\
\hline & \multicolumn{4}{|c|}{ g per tanaman } \\
\hline Tanpa perlakuan stimulan & 18.47 & 4.37 & 177.63 & 18.02 \\
\hline Stimulan sintetik $100 \mathrm{ppm}$ & 22.57 & 4.54 & 195.13 & 23.31 \\
\hline Stimulan sintetik $150 \mathrm{ppm}$ & 26.27 & 5.92 & 210.9 & 23.87 \\
\hline Urin sapi $15 \%$ & 20.73 & 4.38 & 190.93 & 20.06 \\
\hline Urin sapi $25 \%$ & 21.6 & 5.47 & 199.93 & 20.14 \\
\hline Ekstrak bawang merah $40 \%$ & 22 & 5.03 & 191.9 & 20.3 \\
\hline Ekstrak bawang merah $60 \%$ & 20.43 & 5.4 & 202.4 & 23.22 \\
\hline $\mathrm{KK}(\%)$ & 16.28 & $16.18^{\mathrm{T}}$ & $12.28^{\mathrm{T}}$ & $11.37^{\mathrm{T}}$ \\
\hline Respon & tn & $\operatorname{tn}$ & tn & $\operatorname{tn}$ \\
\hline
\end{tabular}

Keterangan: ${ }^{\mathrm{tn}}$ : tidak berpengaruh nyata; $\mathrm{KK}=$ koefisien keragaman; ${ }^{\mathrm{T}}=$ data ditransformasikan $\mathrm{ke} \sqrt{\mathrm{x}+0.5}$

Bobot segar akar dan bobot kering akar berhubungan dengan jumlah dan panjang akar. Bobot akar menentukan bobot brangkasan yang dihasilkan. Purwanti (2008) menyatakan bahwa pertumbuhan yang baik di bagian atas tanaman akan merangsang pertumbuhan dibagian bawah. Volume akar akan membesar dan memperluas jangkauan akar untuk memperoleh makanan lebih banyak, sehingga mendukung pertumbuhan bagian atas tanaman. Produksi bahan segar dan bahan kering tanaman dipengaruhi oleh penerimaan penyinaran matahari dan pengambilan karbon dioksida dan air oleh tumbuhan yang diperlukan dalam proses fotosintesis. Proses fotosintesis membutuhkan banyak air, sehingga akan memicu pertumbuhan akar untuk mencari air.

\section{KESIMPULAN}

Aplikasi stimulan sintetik dan alami tidak efektif terhadap pertumbuhan setek pucuk torbangun. Setek dengan aplikasi stimulan sintetik $150 \mathrm{ppm}$ menghasilkan persentase hidup $100 \%$, tinggi $14.31 \mathrm{~cm}$, jumlah daun per setek 30.46, panjang akar $26.98 \mathrm{~cm}$, jumlah akar 23.99, berat segar akar 26.27 g per tanaman, berat kering akar 5.92 g per tanaman, berat segar brangkasan 210.90 g per tanaman, dan berat kering brangkasan 23.87 g per tanaman.

\section{DAFTAR PUSTAKA}

Alfitra P. 2010. Formulasi minuman suplemen daun torbangun (Coleus amboinicious Lour) untuk wanita yang menderita PMS (Pramenstruasi Syndrome). [skripsi]. Bogor (ID): Institut Pertanian Bogor. Budianto EA, Badami K, Arsyadmunir A. 2013. Pengaruh kombinasi macam ZPT dengan lama perendaman yang berbeda terhadap keberhasilan pembibitan sirih merah (Piper crocatum Ruiz dan Pav) secara setek. J Agrovigor: 6(2): 10-111.

Dewi AL. 2011. Formulasi cookies berbasis pati garut (Maranta arundinaceae Linn) dengan penambahan tepung torbangun (Coleus amboinicus Lour) sebagai sumber zat gizi mikro. [skripsi]. Bogor (ID): Institut Pertanian Bogor.

[Diperta Jabar]. Dinas Pertanian Jawa Barat . 2012. Mengenal sayuran indigenous [Internet]. [Diunduh 2015 Nov 2]. Tersedia pada: http://www.diperta.jabar.prov.go.id/index.p hp/subMenu/informasi/.

Hossain MA, Bhuiyan MK. 2006. Clonal propagation guava (Psidium guajava Linn.) by stem cutting from mature stock plants. J For Res. 17(4): 301-304.

Kaliappan ND, Viswanathan PK. 2008. Pharmacognostical studies on the leaves of Plectranthus amboinicus Spreng. Int $J$ Green Pharm. 2(3): 182-184.

Karimah A, Purwanti S, Rogomulyo R. 2013. Kajian perendaman rimpang temulawak (Curcuma xanthorriza Roxb.) dalam urin sapi dan air kelapa untuk mempercepat percabangan. J Vegetalika. 2(2): 1-8

Khair H, Meizal, Hamdani ZR. 2013. Pengaruh konsentrasi ekstrak bawang merah dan air kelapa terhadap pertumbuhan setek tanaman melati putih (Jasminum sambac L.). J Agrium. 18(2): 130-138.

Kusumah YSA, Karno, Sutarno. 2012. Perbanyakan vegetatif cara stek Desmodium cinereum dan Hibiscus rosa sinensis L. dengan pemberian zat pengatur tumbuh alami dan auksin 
sintetis. J Animal Agriculture. 1(1): 557565 .

Lakitan B. 2006. Dasar-Dasar Fisiologi Tumbuhan. Jakarta (ID): Raja Grafindo Persada.

Mahfudz MA, Fauzi, Adinugraha HA. 2003. Pengaruh media dan dosis Rootone-F terhadap keberhasilan setek pucuk pulai ((L.) R.Br.). $J$ Pemuliaan Tanaman Hutan.1(1) : 1-9.

Mashudi. 2011. Pengaruh asal populasi dan komposisi media terhadap keberhasilan setek pucuk pulai darat (Miq.). $J$ Pemuliaan Tanaman Hutan. 5(3): 159-168.

. 2013. Pengaruh provenan dan komposisi media terhadap keberhasilan teknik penunasan pada setek pucuk pulai darat. $J$ Penelitian Tanaman Hutan. 10(1): 25-32.

McMahon MJ, Kofranek AM, Rubatzky VE. 2007. Hartsman's Plan Science Growth Development and Utilization of Cultivated Plants. 4th ed. New York (US): Ohio Pearson Prentice Hall. Muhammad W. 2002. Penggunaan arang tempurung kelapa sebagai sorben penurunan cemaran kimiawi limbah cair sapi perah. [skripsi]. Bogor (ID): Institut Pertanian Bogor.

Prastyono, Adinugraha HA, Suwandi. 2003. Keberhasilan pertumbuhan setek pucuk Eucalyptus pellita F. Muel pada beberapa media dan hormon perangsang pertumbuhan. $J$ Pemuliaan Tanaman Hutan. 1(2) : 63-70.

Purwanti, E. 2008. Pengaruh dosis pupuk majemuk dan konsentrasi EM-4 terhadap pertumbuhan bibit setek tebu (Saccharum officinarum L.). [skripsi]. Surakarta (ID): Universitas Sebelas Maret. Putri DMS,

Sudianta NI. 2009. Aplikasi penggunaan ZPT pada perbanyakan Rhododendron javanicum Benn. (Batukau, Bali) secara vegetatif (setek pucuk). J Biol. 1(13): 1720.

[RHS] Royal Horticulture Society. 2008. RHS A-Z encyclopedia of garden plants. [Internet]. [Diunduh 2015 Nov 15]. Tersedia pada: http://www.rhs.org.uk.

Rumetor SD. 2008. Suplementasi daun bangunbangun (Plectranthus amboinicus Spreng.) dan zinc-vitamin $\mathrm{E}$ dalam ransum untuk memperbaiki metabolisme dan produksi susu kambing peranakan etawah [disertasi]. Bogor (ID): Institut Pertanian Bogor.

Siskawati E, Linda R, Mukarlina. 2013. Pertumbuhan stek batang jarak pagar (Jatropha curcas L.) dengan perendaman larutan bawang merah (Allium cepa L.) dan IBA (Indol Butyric Acid). J Protobiont. 2(3): 167-170.

Sudomo A, Rohandi A, Mindawati N. 2013. Penggunaan zat pengatur tumbuh RootoneF pada setek pucuk manglid (Manglietia glauca BI). J Penelitian Tanaman Hutan. 10(2): 57-63.

Wiratri N. 2005. Pengaruh cara pemberian Rootone F terhadap induksi akar setek Gmelina (Gmelina arborea Linn). [skripsi]. Bogor (ID): Institut Pertanian Bogor. 